Uniwersytet Jagielloński

krzysztof.dziurzynski@gmail.com

\title{
Who do Poles trust? SECONDARY ANALYSIS OF ESS 2014 DATA USING FACTOR ANALYSIS, ANALYSIS OF RELIABILITY AND ANALYSIS OF VARIANCE
}

\author{
Komu Polacy Ufają? \\ ANALIZA WTÓRNA DANYCH ESS 2014 \\ Z ZASTOSOWANIEM ANALIZY CZYNNIKOWEJ, \\ ANALIZY RZETELNOŚCI ORAZ ANALIZY WARIANCJI
}

\begin{abstract}
Trust is a multidimensional variable and a number of one-dimensional variables are needed to measure it. These variables may refer to state institutions, political institutions, people, media, etc. The more variables used to determine the unit level of trust, the harder it is to identify a hidden variable that will replace several one-dimensional variables in further research. Trust is such a hidden variable. Of course, you can ask the question: do you generally trust? The answer to this question is dichotomous: yes or no trust. But will the researcher know who trusts whether it is a person or an institution and what is very important to what degree he trusts. Thus, the seemingly simple research task at the conceptualization stage begins to complicate, grow and make the researcher reach for a more extensive research tool. The presented article will analyze the problems of Poles' trust. Data comes from the seventh round of the 2014 European Social Survey. 1616 people aged over 16 took part in it. The obtained results were subjected to analysis allowing to determine multidimensionality (factor analysis) and scale reliability (Cronbach's alpha). As the main cognitive goal, the determination of the perception of the dimensions of trust was accepted. Originally, it was assumed that five one-dimensional variables would allow the reproduction of two latent variables (components) that would simplify the
\end{abstract}


analysis of trust. It was also assumed that (1) sex, (2) age, (3) education and (4) place of residence will significantly differentiate the level of trust. It was also decided to present the level of confidence of Poles against the background of other countries participating in the ESS.

\section{STRESZCZENIE}

Zaufanie jest zmienną wielowymiarową i do jego pomiaru konieczna jest pewna liczba jednowymiarowych zmiennych. Zmienne te mogą odnosić się do instytucji państwowych, politycznych, osób, mediów itp. Im więcej zmiennych użytych jest do określenia jednostkowego poziomu zaufania, tym trudniej jest wyłonić zmienną ukrytą, która w dalszym postępowaniu badawczym zastąpi kilka zmiennych jednowymiarowych. Taką zmienną ukrytą jest zaufanie. Oczywiście można zadać pytanie: czy generalnie Pan/Pani ufa? Odpowiedź na tak postawione pytanie ma charakter dychotomiczny: tak lub nie. Ale czy badacz będzie wiedział, komu badany ufa, czy jest to osoba, czy instytucja i co bardzo ważne - w jakim stopniu ufa. Zatem na pozór proste zadanie badawcze na etapie konceptualizacji zaczyna się komplikować, rozrastać i każe badaczowi sięgać po bardziej rozbudowane narządzie badawcze. W prezentowanym artykule przeanalizowana zostanie problematyka zaufania Polaków. Dane pochodzą z siódmej rundy międzynarodowego badania porównawczego European Social Survey (Europejski Sondaż Społeczny) z 2014 r. Wzięło w nim udział 1616 osób w wieku powyżej 16. roku życia. Uzyskane wyniki poddano analizie pozwalającej na określenie wielowymiarowości (analiza czynnikowa) i rzetelności skali (alfa Cronbacha). Jako główny cel poznawczy przyjęto określenie postrzegania wymiarów zaufania. Pierwotnie założono, że pięć jednowymiarowych zmiennych pozwoli na odtworzenie dwóch zmiennych latentnych (składowych), które uproszczą analizę. Przyjęto także założenie, że płeć, wiek, wykształcenie oraz miejsce zamieszkania będą istotnie różnicować poziom zaufania. Postanowiono także zaprezentować poziom zaufania Polaków na tle pozostałych krajów uczestniczących w badaniu ESS.

KEYWORDS: Europeen Social Survey, trust, factor analysis, analysis of reliability, analysis of variance

SŁOWA KLUCzOWE: Europejski Sondaż Społeczny, zaufanie, analiza czynnikowa, analiza rzetelności, analiza korespondencji, analiza wariancji

\section{WPROWADZENIE}

W naukach społecznych coraz częściej spotykamy się z wtórną analizą danych. „Z ogólnego punktu widzenia dane wtórne mogą być jedynymi dostępnymi danymi dla określonych problemów badawczych" (Frankfort- 
-Nachmias, Nachmias, 2000, s. 322). Herbert H. Hyman podkreślił znaczenie danych zastanych dla lepszego zrozumienia kontekstu historycznego, kulturowego czy społecznego (Hyman, 1987). Przeprowadzając analizę danych pozyskanych z badań cyklicznych, badacze mogą opisać i wyjaśnić zmiany. Dane, do jakich odwołujemy się w tym artykule, pozwalają opisać i wyjaśnić m.in. stabilność i zmianę poglądów, postaw, zaufania do instytucji publicznej, identyfikację z partiami politycznymi, zachowania wyborcze (ESS Round 7, European Social Survey Round 7 Data, 2014. Data file edition 2.1. NSD - Norwegian Centre for Research Data, Norway - Data Archive and distributor of ESS data for ESS ERIC). Posługując się słowami H. Hymana, można powiedzieć, iż „osoba dokonująca wtórnej analizy danych musi przeanalizować szeroki zakres szczegółowych wskaźników, różnorodne zachowania czy postawy” (Hyman, 1988, s. 24). Norval Glenn zauważył ponad 40 lat temu, że „zachodzi właśnie (...) zmiana w badaniach sondażowych. Jeszcze niedawno dane $\mathrm{z}$ sondaży były analizowane przede wszystkim przez osoby prowadzące te sondaże. Teraz zaś (w połowie lat 80. - K.Dz.) obserwujemy silną tendencję do rozdzielania planu sondażu od analizy danych. Można sobie wyobrazić czas, kiedy niektórzy badacze prowadzący badania sondażowe będą się specjalizować w tworzeniu planów takich badań, a inni w przeprowadzaniu analiz danych pochodzących z tych badań” (Glenn, 1978, s. 532).

Badacz, chcąc dokonać opisu długofalowych zmian, ma możliwość dokonywania wielu porównań w czasie i w przestrzeni. Przykładem takich właśnie danych jest osiem rund wspomnianego już Europejskiego Sondażu Społecznego.

Zaufanie jest tematem dociekań badawczych od blisko 50 lat. Najstarsze źródło bibliograficzne przywołane przez Piotra Sztompkę sięga 1972 r. (Sztompka, 2007, s. 412). Pół wieku tradycji teoretycznej i badawczej to wystarczająco dużo czasu, by mniej lub bardziej dokładnie opisać i wyjaśnić ten problem. Jednak co pewien czas badacze powracają do problematyki zaufania.

W zasadzie możemy przyjąć, że mniej lub bardziej precyzyjnie wiemy, co znaczy ufać. Słowo „zaufanie” dość często pojawia się zarówno w codziennym rozmowach, jak i w opracowaniach naukowych. By uniknąć przekłamań, odwołamy się do jego dwóch definicji. Pierwsza z nich pochodzi ze Słownika psychologii (2005), którego autorzy wyróżniają dwa znaczenia tego pojęcia. 
Pierwsze odnosi się do wiary w prawdomówność danej osoby. Drugie odnosi się do zwrotu „w zaufaniu”, czyli przekazania sekretnej informacji i oznacza jej poufność, nierozpowszechnianie (Słownik psychologii, 2005, s. 919).

Druga definicja pochodzi z Uniwersalnego słownika jezzyka polskiego (2003), który podaje trzy znaczenia słowa „ufać”. Pierwsze oznacza mieć przekonanie, że ktoś nie oszuka, nie zrobi niczego złego, to wierzyć komuś, polegać na kimś, być kogoś pewnym. Drugie odwołuje się do przekonania, że czyjeś słowa, przekazane przez daną osobę informacje są prawdziwe. Trzecie rozumienie oznacza wiarę w czyjeś umiejętności, zdolności, jak również to, że ten ktoś potrafi je odpowiednio wykorzystać.

Synonimem słowa „ufać” jest zwrot „uważać kogoś za autorytet”. Ten sam Słownik języka polskiego definiuje „zaufanie” jako przeświadczenie, przekonanie, że czyjeś słowa i przekazane przez daną osobę informacje są prawdziwe, że coś jest dobre i pożyteczne. Synonimem tego słowa jest „zawierzenie”. Stąd już blisko do wiary. Jednak zaufanie w polityce nie sprowadza się li tylko do słów. Za słowami stoją czyny, działania, konkretne decyzje. Z pojęciem tym wiąże się autorytet. To przecież autorytetom się ufa.

Piotr Sztompka $(1994,1995)$ wskazuje na znaczenie zaufania jako fundamentalnego zasobu społecznego warunkującego potencjał, którym dysponują podmioty działające w określonym społeczeństwie. Zwraca uwagę na funkcję zaufania w postaci pola dla inicjatywy, innowacji i swobodnego działania oraz na konsekwencje deficytu zaufania, gdy pojawiają się substytuty funkcjonalne w postaci korupcji, kontroli społecznej, fatalizmu, zamykania się w społecznym getcie, ucieczki w objęcia autokratycznych czy populistycznych wodzów, czy zwrotu ku zewnętrznym, często wyidealizowanym, społecznościom czy grupom (1995).

Najpełniejszą - w interesującym nas kontekście - definicję zaufania formułuje Francis Fukuyama (1997, s. 39). W jego rozumieniu zaufanie jest wyłaniającym się w obrębie wspólnoty oczekiwaniem regularnych, uczciwych i kooperatywnych zachowań opartych na powszechnie podzielanych przez innych członków tej wspólnoty normach. Mogą one dotyczyć kwestii dotyczących wartości, jak natura Boga lub sprawiedliwości, lecz również obejmują normy świeckie, np. standardy profesjonalne i kodeksy zachowania.

Zdaniem Jamesa Colemana i Roberta Putnama zaufanie to kapitał spo- 
łeczny, który powinien cechować grupy społeczne, społeczeństwo dążące do rozwoju pojmowanego jako postęp społeczny, w znanym i jasno określonym kierunku (Coleman, 1988; Putnam, 1995).

Z tego przeświadczenia wypływa wiara jednostek, grup społecznych, społeczeństwa, że politycy - instytucje i organizacje funkcjonujące na scenie politycznej - działają na ich korzyść, nie kierują się zaś wąsko pojętym partykularnym interesem klasy politycznej. Zaufanie jest oczekiwaniem stanu przyszłego. Zaufanie to istotny motyw zachowania.

Francis Fukuyama dowodzi, że dobrobyt narodu, jak również jego zdolność do konkurowania na międzynarodowym rynku są uwarunkowane przez właściwy społeczeństwu poziom zaufania (1997). Jego zdaniem kraje o wysokim poziomie zaufania do instytucji i wysokim poziomie zaufania społecznego cechuje wysoka efektywność gospodarcza, wyższa skłonność do współpracy i samoorganizacji, częstsze postępowanie zgodnie ze wspólnymi normami i wartościami.

Uwaga ta wydaje się być trafna nie tylko w odniesieniu do sfery ekonomii, ale także - a może przede wszystkim, do sfery społecznej życia zbiorowego.

Krzysztof Nowakowski (2008) zauważa, że zaufanie do instytucji państwowych „redukuje koszty wdrażania reguł prawnych i kreuje działania zbiorowe" (2008). Na związek zaufania z bezpieczeństwem zwróciła uwagę Katarzyna Ferszt-Piłat (2012).

Relacje między obywatelem a instytucjami życia publicznego to relacje zaufania. Czymże byłaby władza, gdyby jej nie ufano? Władza ta byłaby samotnym bytem istniejącym w oderwaniu od społeczeństwa, od swojego zaplecza. Jak wyglądałoby społeczeństwo, w którym kapitał zaufania zostałby roztrwoniony? Byłoby zamknięte, podzielone na niezliczoną liczbę małych grup, którym przewodziliby tyrani.

Dlatego problematyka funkcjonowania instytucji politycznych warta jest przeanalizowania właśnie w kontekście zaufania. Od lat zadawane są na różne sposoby pytania z kategorii „czy ufasz?”, „komu ufasz” i „w jakim stopniu ufasz?”. Pytania dotyczą różnych podmiotów polityki: instytucji, partii politycznych, źródeł informacji politycznych, polityków, mężów stanu. Przykładem takiego szerokiego podejścia badawczego są cykliczne badania Centrum Badania Opinii Społecznej (Zaufanie społeczne, komunikat nr 18/2016). 
Dla potrzeb prezentowanego artykułu przyjęto, że zaufać komuś to być przekonanym o jego umiejętnościach, zdolnościach, o wartości tego, co robi, co sobą reprezentuje. W życiu publicznym można zaobserwować wiele różnych instytucji, które z racji swojego uwikłania w politykę, interesy społeczne winny być takimi autorytetami i powinny posiadać potencjał zaufania.

Stosunek do instytucji życia publicznego to także bardzo konkretny wymiar postaw wobec polityki. To również wskaźnik akceptacji ich praktycznej działalności.

\section{METOdOLOGICZNE PODSTAWY PRZEPROWADZONYCH ANALIZ}

Jakim zaufaniem cieszą się polskie instytucje życia publicznego? Czym jest uwarunkowane zaufanie do nich? Jaki jest potencjał zaufania polskich instytucji politycznych? Jak Polacy gospodarują kapitałem społecznym? Czy Polacy są społeczeństwem dobrze zagospodarowanego kapitału zaufania, czy też roztrwaniają go? Jak jest w rzeczywistości, postanowiono rozstrzygnąć, sięgając do uznanego w międzynarodowej przestrzeni badawczej badania European Social Survey.

Sformułowano pytania badawcze brzmiące następująco:

1. Jaki jest poziom zaufania Polaków do instytucji życia publicznego i politycznego?

2. Jaki jest poziom zaufania Polaków na tle pozostałych krajów uczestniczących w siódmej rundzie ESS w 2014 r.?

3. Czy w myśleniu Polaków o zaufaniu do instytucji życia publicznego i politycznego istnieją konstrukty ukryte (czynniki, składowe)? Jeśli tak, to ile ich jest?

4. Czy płeć, wiek, wykształcenie oraz miejsce zamieszkania badanych Polaków różnicuje poziom zaufania do instytucji życia publicznego i politycznego?

Pierwotnie założono, że pięć jednowymiarowych zmiennych pozwoli na odtworzenie dokładnie dwóch zmiennych latentnych (składowych), które uproszczą dalsze analizy dotyczące zaufania Polaków do instytucji życia publicznego i politycznego (Sagan, 2003, s. 39).

Przyjęto także cztery hipotezy mówiące, że płeć, wiek, wykształcenie oraz miejsce zamieszkania będą istotnie różnicować poziom zaufania. 
W kwestionariuszu ESS, którego koncepcja oraz podstawy metodologiczne oraz dane są od lat dostępne na platformie dedykowanej temu projektowi (dostęp do nich jest powszechny, nieograniczony i bezpłatny, http://www. europeansocialsurvey.org/data/ [dostęp: 6.02.2018]) znalazło się wiele pytań zaczynających się od sformułowania: „W jakim stopniu ufa Pan/Pani?”. Każde z pytań odnosiło się do osobnego podmiotu życia politycznego. Były to zarówno instytucje państwowe o charakterze stricte politycznym - sejm, instytucje państwowe konstytucyjnie oddzielone od polityki (sądy, policja), jak i instytucje polityczne (politycy i partie polityczne). Respondenci mieli za zadanie ocenić każdą z tych instytucji, posługując się jedenastostopniową skalą od „absolutnie nie ufam” (wartość 0 na skali) do „zdecydowanie ufam” (wartość 10 na skali). Tak skonstruowana skala posiada bardzo wyraźnie określone trzy punkty oceny: 0 - brak zaufania, 5 - średni poziom zaufania oraz 10 - całkowite zaufanie. Na podstawie analizy struktury skali można podzielić ją na pięć kategorii. Pierwsza z nich (wartość 0) odnosi się do absolutnego braku zaufania, druga (obejmująca wartości od 1 do 4) wskazuje na niskie zaufanie. Trzecia z nich (wartość 5) odnosi się do średniego zaufania. Czwarta kategoria zawiera wartości od 6 do 9 i odnosi się do wysokiego zaufania. Ostatnią, piątą, kategorię stanowi wartość 10 i odpowiada ona całkowitemu zaufaniu.

Respondenci mogli także odmówić odpowiedzi. W zależności od instytucji w przypadku polskich danych było od $0,7 \%$ do $2,0 \%$ braków danych.

W analizie zostały zastosowane zróżnicowane metody statystyczne: statystyki opisowe, porównywanie średnich z użyciem jednoczynnikowej analizy ANOVA, analiza czynnikowa, analiza rzetelności (alfa Cronbacha) oraz analiza korespondencji. Analizy statystyczne zostały przeprowadzone za pomocą SPSS v.24 (Predictive Solutions).

Zbudowany także został syntetyczny zgeneralizowany wskaźnik zaufania. Do jego budowy posłużono się analizą czynnikową, a wartości czynnika wyłoniono metodą Andersona-Rubina.

Do oceny wymiarowości zastosowano analizę czynnikową (Thurstone, 1931; Górniak, 2000, s. 311-329). Analizę czynnikową przeprowadzono metodą osi głównych. W celu ustalenia zasadności użycia analizy czynnikowej do identyfikacji wymiarów zastosowano wskaźnik Kaisera-Mayera-Olkina 
$(0,785)$, który wskazuje na odpowiedni dobór próby i zmiennych do analizy czynnikowej. Wskaźnik Kaisera-Mayera-Olkina (K-M-O) wyniósł 0,785 i jest większy od 0,5, co wskazuje na zasadność wykorzystania w identyfikacji składowych (wymiarów) analizy czynnikowej (Sztemberg-Lewandowska, 2008, s. 33-34; Malarska, 2005, s. 212; Górniak, 2000, s. 328). Test sferyczności Bartletta $\mathrm{H}_{0}$ zakłada, że macierz korelacji jest macierzą jednostkową. W prezentowanym przypadku $(p<0,001)$ odrzucamy $\mathrm{H}_{0}$ na rzecz hipotezy alternatywnej, mówiącej, że otrzymana macierz korelacji nie jest macierzą jednostkową i możliwe było zastosowanie analizy czynnikowej (Rószkiewicz, 2011, s. 36; Malarska, 2005, s. 211, 217).

Liczba czynników była wyznaczona arbitralnie przez kryterium Kaisera - był to 1 czynnik do wyodrębnienia (Kaiser, 1960, s. 141-151). Także wykres osypiska wskazał jeden czynnik. Początkowa wartość własna czynnika, przed wyodrębnieniem, wyniosła 3,297, wyjaśniając 65,94\% wariancji. Ważnym elementem analizy czynnikowej jest wybór metody rotacji. Wybór metody opiera się na oczekiwaniu, czy zmienne latentne (czynniki, składowe) będą skorelowane (Oblimin, Quartimin, Promax), czy też nie (Varimax, Quatrimax, Equamax). Rotacje Varimax i Oblimin nie wyróżniają jednego czynnika kosztem innych (tak jak to ma miejsce w rotacji Equamax).

Wewnętrzną spójność utworzonego wskaźnika (skali) zbadano za pomocą analizy rzetelności i współczynnika alfa Cronbacha (Cronbach, 1946, s. 47-48; Górniak, 2000, s. 68-72). Stosuje się ją dopiero po ocenie wymiarowości (Carmines, Zeller, 1980, s. 154-234). Alfa Cronbacha informuje, czy sposób udzielania odpowiedzi na poszczególne pytania był spójny, czy przypadkowy.

Rzetelność mówi o tym, z jaką dokładnością dany wymiar (czynnik, składowa) mierzy to, co mierzy. Wymiar otrzymany posiada wysoką rzetelność, gdy osiągnął wartość 0,859 (Cronbach, 1946, s. 47-48).

\section{ZAUFANIE DO INSTYTUCJI ŻYCIA PUBLICZNEGO W KRAJACH EUROPY}

Zaufanie społeczne do instytucji życia publicznego w Europie jest zróżnicowane. Naukowcy tłumaczą to zróżnicowanie niejednakowym doświadczeniem państw Europy wynikającym z odmiennego funkcjonowania instytucji demokratycznego państwa prawa. Zasada państwa prawa po raz pierwszy 
została wyraźnie sformułowana w Niemczech w konstytucji z 1949 r. Artykuł 28 stanowił, iż „porządek konstytucyjny krajów związkowych musi odpowiadać republikańskim, demokratycznym i socjalnym zasadom państwa prawa” (Ustawa Zasadnicza Republiki Federalnej Niemiec z 23 maja 1949 r.).

W drugiej połowie XX w. zasada ta była zapisywana również w innych konstytucjach demokratyzujących się krajów (Hiszpanii, Portugalii, Grecji). W konstytucji Hiszpanii z 1978 r. została ujęta w art. 1, zgodnie z którym „Hiszpania konstytuuje się w postaci społecznego i demokratycznego państwa prawnego, które chroni jako najwyższe wartości swego porządku prawnego wolność, sprawiedliwość, równość i pluralizm polityczny” (Konstytucja Hiszpanii z dnia 27 grudnia 1978 r.).

Po 1989 r. zasada państwa prawa była wprowadzana do konstytucji państw postkomunistycznych.

Do polskiego prawa zasadę demokratycznego państwa prawnego wprowadziła Ustawa z dnia 29 grudnia 1989 r. o zmianie Konstytucji Polskiej Rzeczypospolitej Ludowej, która weszła w życie 31 grudnia 1989 r.

Koncepcja ta zakłada, że stanowione w procesie demokratycznym prawo ma pozycję nadrzędną w systemie politycznym, wiąże rządzących i wyznacza zakres ich kompetencji, a obywatelom gwarantuje szereg praw i wolności. W państwie prawa organy i instytucje państwowe mogą działać jedynie w zakresie określonym przez prawo, natomiast obywatele mogą czynić to wszystko, czego prawo nie zakazuje (Zakrzewska, 1992, s. 325-334).

Na wykresie 1 przedstawiono średnie poziomy zaufania do parlamentów narodowych. Kraje zostały uporządkowane wg średniej wartości zaufania. Uporządkowano je w kolejności malejącej. Najwyższym zaufaniem cieszy się Parlament Norwegii (średnia 6,7 pkt). Następne w kolejności są parlamenty: Szwecji (średnia 6,23 pkt), Szwajcarii (średnia 6,21 pkt), Danii (średnia 5,91 pkt), Finlandii (średnia 5,5 pkt), Holandii (średnia 5,19 pkt), Niemiec (średnia 5,0 pkt). Najniższym zaufaniem darzą parlament Słoweńcy (średnia 2,76 pkt) oraz Polacy (średnia 2,80 pkt).

Wśród krajów o najwyższym poziomie zaufania znalazły się cztery monarchie oraz trzy republiki konstytucyjne. Pięć krajów określanych jest w literaturze socjologiczno-politologicznej jako kraje nordyckie, dwa jako kraje Europy Środkowo-Zachodniej. Ostatnie dwie pozycje zajęły dwa kraje postkomunistyczne. 
Wykresy od 2 do 5 pokazują zaufanie do systemu prawnego, policji, polityków i partii politycznych. Chociaż dane dotyczące tych instytucji kształtują się na różnym poziomie (pokazują inną kolejność tych krajów, uplasowanych pod względem wielkości zaufania do poszczególnych instytucji), to jednak względne usytuowanie poszczególnych grup krajów pozostaje w zasadzie podobne. Na końcu są niezmiennie Polska i Słowenia.

W celu zredukowania pięciozmiennowej struktury zaufania zbudowany został jeden syntetyczny zgeneralizowany wskaźnik zaufania. Jego średnie wartości dla poszczególnych państw przedstawia wykres 6. Kraje zostały uporządkowane wg malejącej średniej wartości wskaźnika zaufania. Najwyższy poziom zgeneralizowanego wskaźnika zaufania odnotowano w Norwegii. Druga z kolei jest Szwajcaria. W dalszej kolejności są Dania, Szwecja, Finlandia oraz Holandia, Niemicy i Belgia. Austria uzyskała poziom zbliżony dla wszystkich państw uczestniczących w siódmej rundzie ESS. Najniższy poziom zgeneralizowanego wskaźnika zaufania odnotowano wśród Polaków i Słoweńców.

Wykres 1.

Średnie wartości zaufania do parlamentu w 2014 r. w świetle wyników ESS

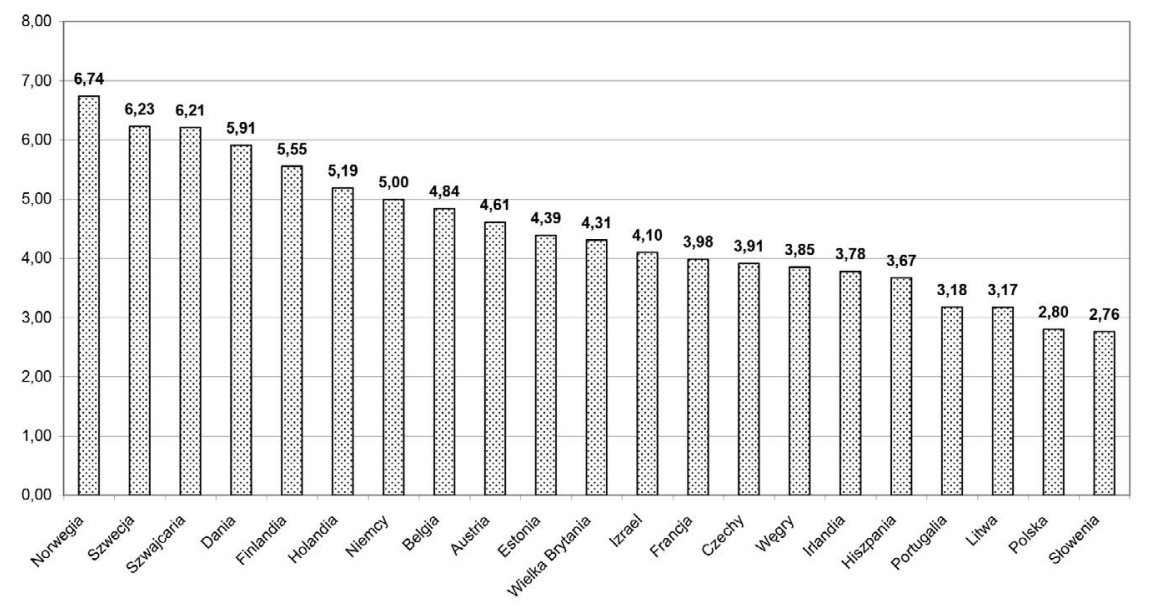

Źródło: dane z siódmej rundy ESS, $2014 \mathrm{r}$. 
Wykres 2.

Średnie wartości zaufania do systemu prawnego w 2014 r. w świetle wyników ESS

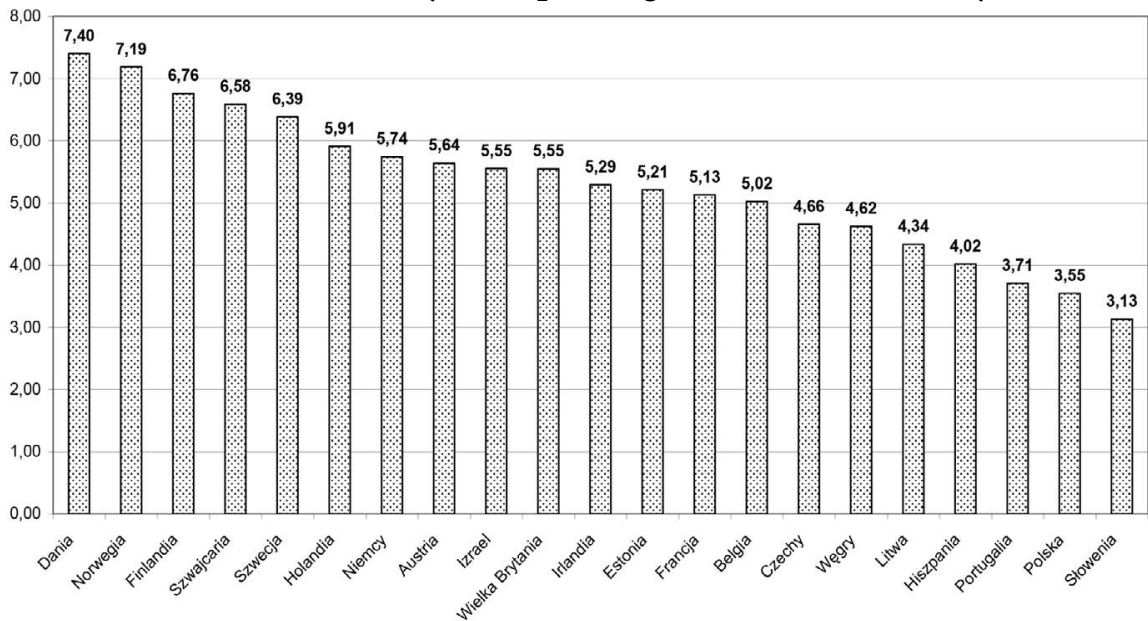

Źródło: dane z siódmej rundy ESS, 2014 r.

Wykres 3.

Średnie wartości zaufania do policji w 2014 r. w świetle wyników ESS

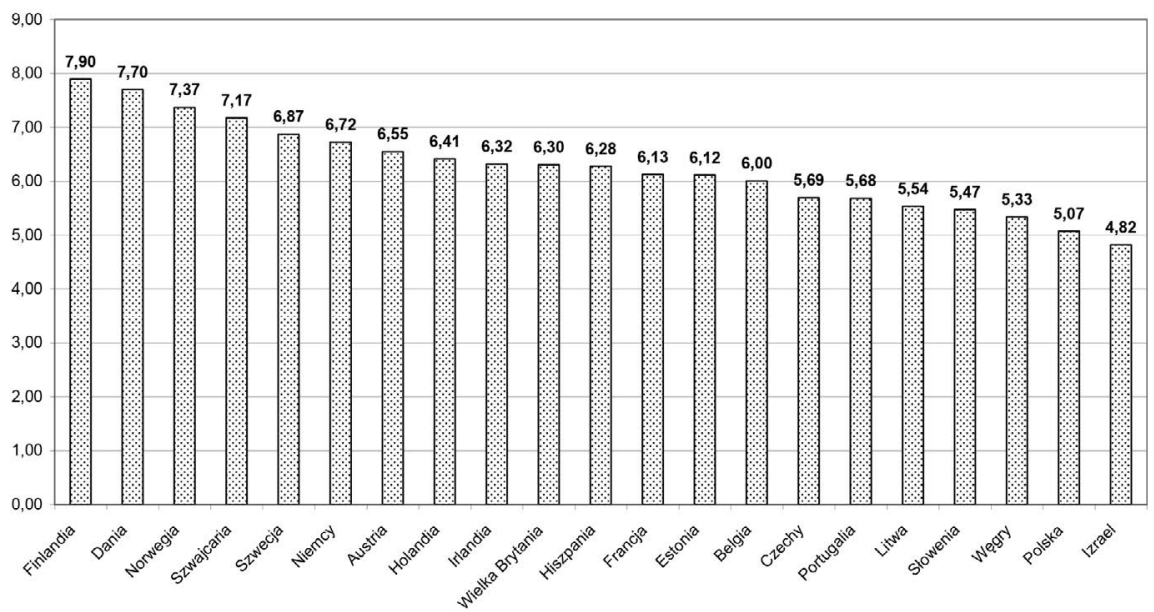

Zródło: dane z siódmej rundy ESS, 2014 r. 
Wykres 4.

Średnie wartości zaufania do polityków w 2014 r. w świetle wyników ESS

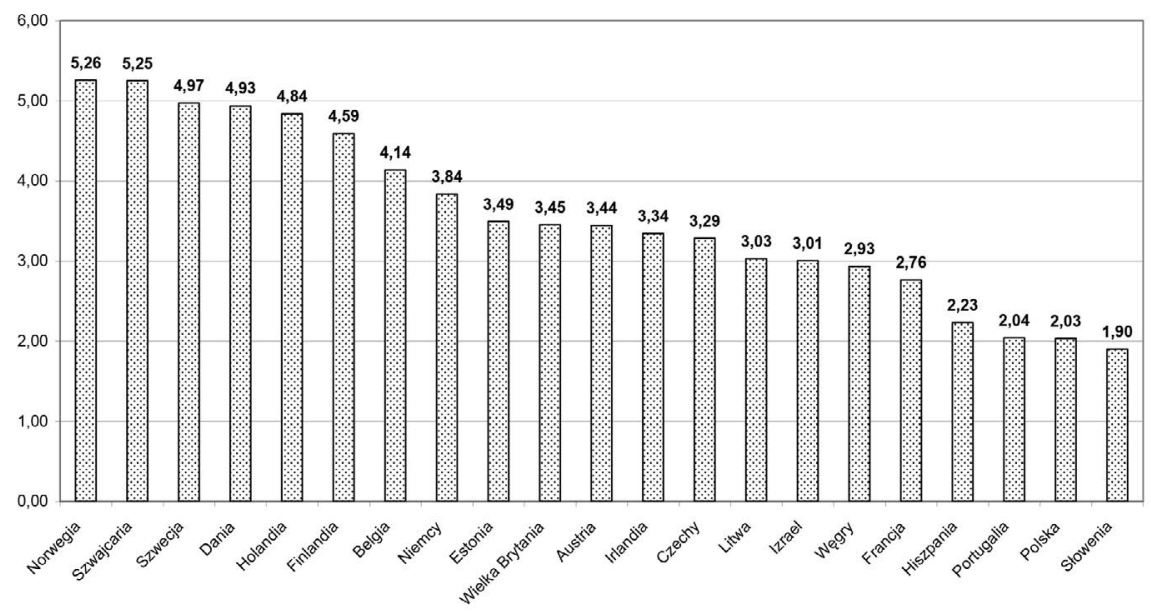

Źródło: dane z siódmej rundy ESS, 2014 r.

Wykres 5.

Średnie wartości zaufania do partii politycznych w 2014 r. w świetle wyników ESS

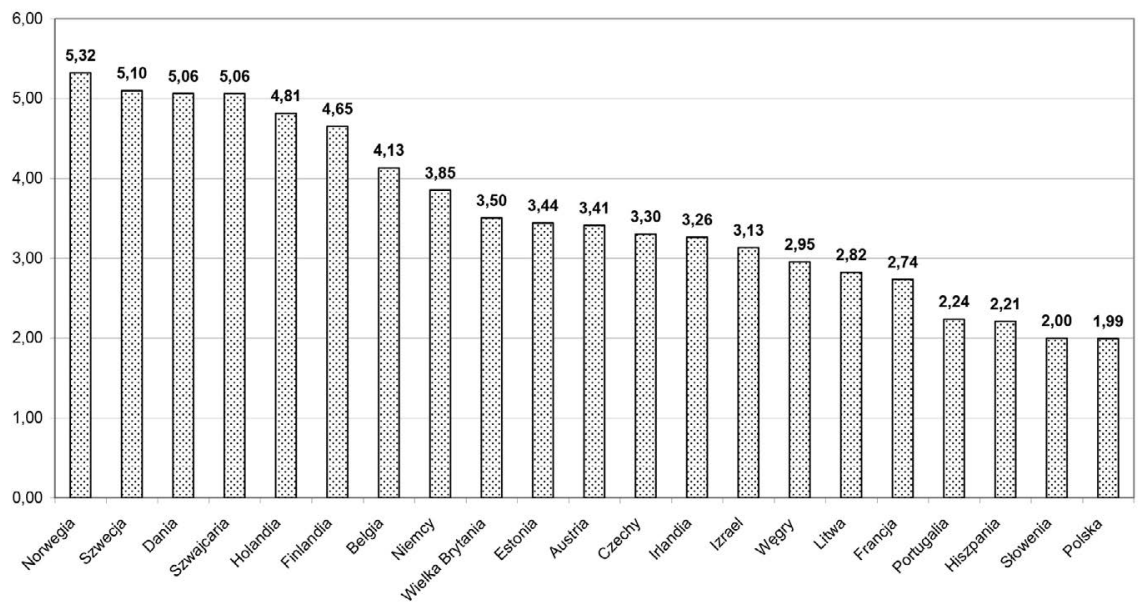

Źródło: dane z siódmej rundy ESS, 2014 r. 
Wykres 6.

Średnie wartości zgeneralizowanego wskaźnika zaufania w 2014 r. w świetle wyników ESS

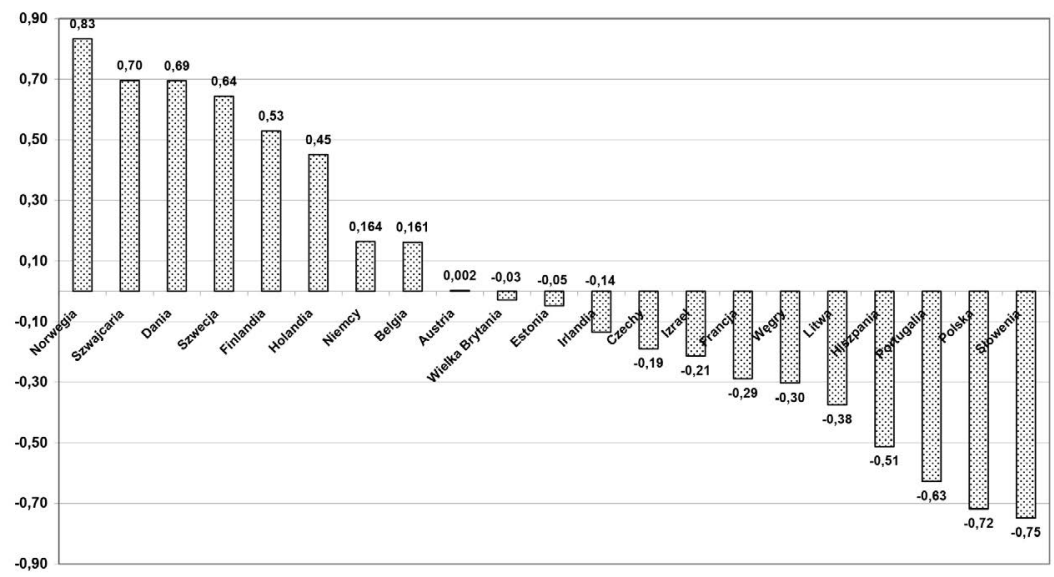

Źródło: dane z siódmej rundy ESS, 2014 r.

\section{Zaufanie Polaków do instytucji żyCia PUBLICZNEGO W BADANIU ESS}

Polska uczestniczyła w projekcie European Social Survey od samego jego początku, tj, od 2002 r. Dzięki temu udało się skompletować niepowtarzalne dane w skali porównawczej pozwalającej na porównanie wyników poszczególnych krajów, jak i porównanie danych w czasie.

Generalnie poziom zaufania Polaków do instytucji państwowych i politycznych jest bardzo niski i po 10 latach powrócił do poziomu z 2004 r. Najlepszy dla Polski w tym obszarze był rok 2010, kiedy to odnotowano najniższą ujemną wartość zgeneralizowanego wskaźnika zaufania. W pozostałych latach, tj. w 2012 i 2014 r., wartość wskaźnika była niższa. Dane te w ujęciu porównawczym pokazuje wykres 7 . Warto zwrócić uwagę na dane przedstawione na wykresach 8 i 9. Pokazują one identyczny wskaźnik dla Szwajcarii i Danii. W tych krajach również miał miejsce spadek wartości tego wskaźnika. Dla Szwajcarii jest to powrót do stanu z 2009 r., zaś dla Danii to powrót do stanu występującego w okresie sprzed 2002 r. Oba te kraje reprezentują poziom, o którym my, Polacy, tylko możemy marzyć. 
Wykres 7.

Średnie wartości zgeneralizowanego wskaźnika zaufania w latach 2002-2014 w świetle wyników ESS

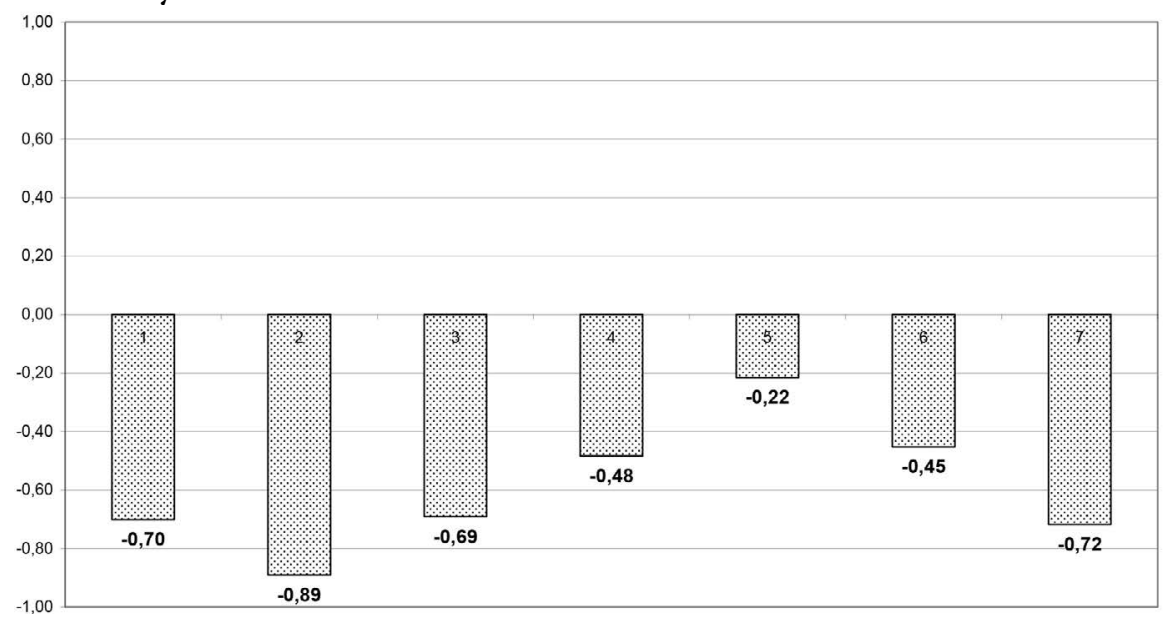

Legenda: Runda ESS 1 - 2002, 2 - 2004, 3 - 2006, 4 - 2008, 5 - 2010, 6 - 2012, 7 - 2014.

Źródło: dane siódmej rundy ESS, $2014 \mathrm{r}$.

Wykres 8.

Średnie wartości zgeneralizowanego wskaźnika zaufania w latach 2002-2014 w świetle wyników ESS - Szwajcaria

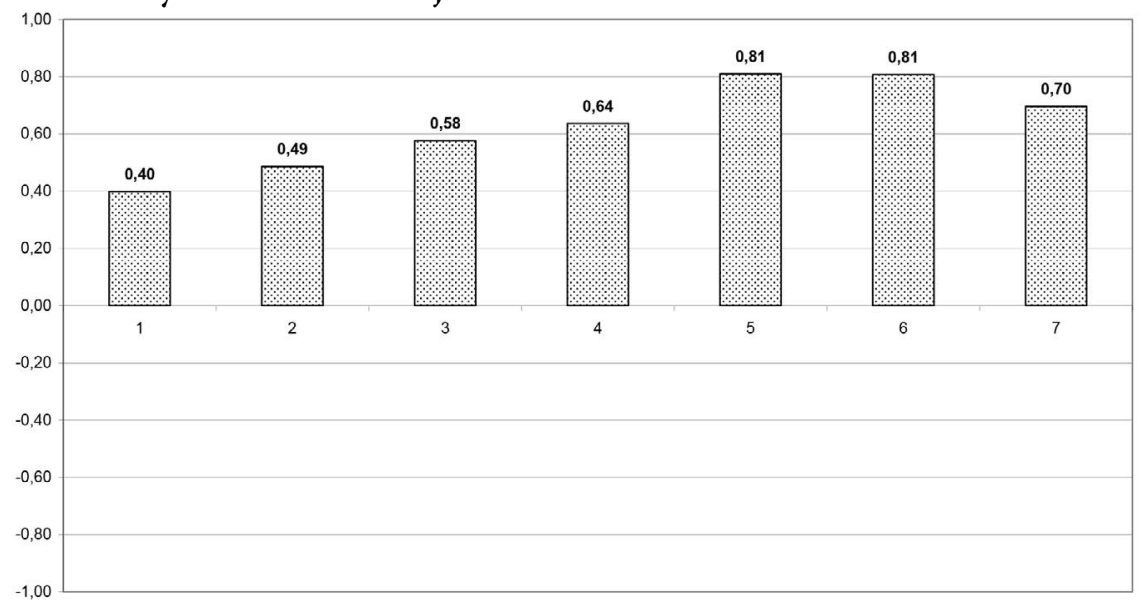

Legenda: Runda ESS 1 - 2002, 2 - 2004, 3 - 2006, 4 - 2008, 5 - 2010, 6 - 2012, 7 - 2014.

Źródło: dane z siódmej rundy ESS, 2014 r. 
Wykres 9.

Średnie wartości zgeneralizowanego wskaźnika zaufania w latach 2002-2014 w świetle wyników ESS - Dania

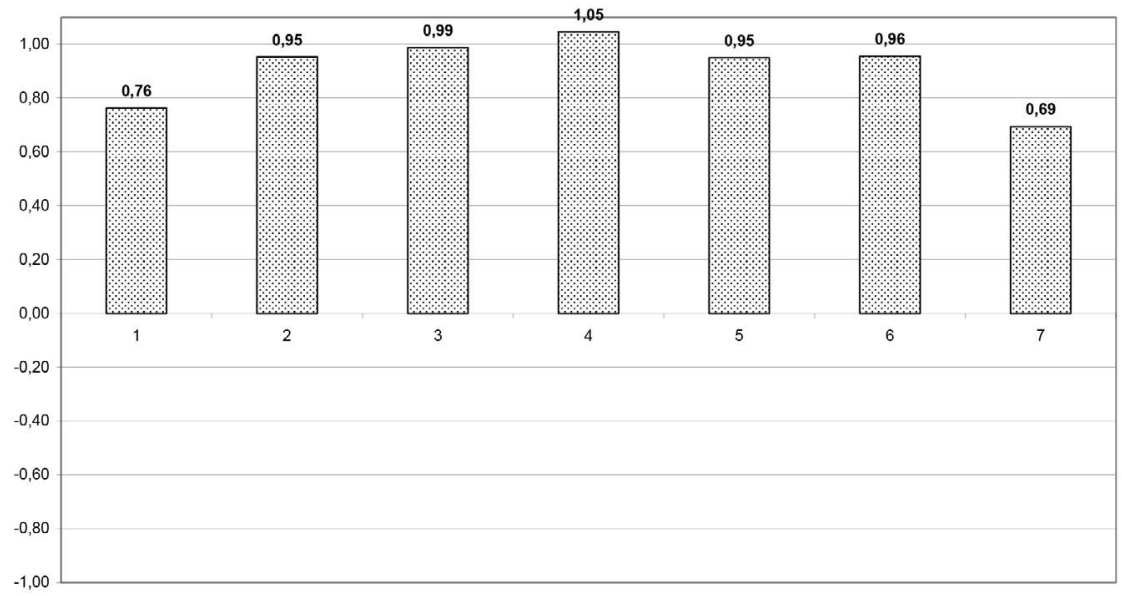

Legenda: Runda ESS 1 - 2002, 2 - 2004, 3 - 2006, 4 - 2008, 5 - 2010, 6 - 2012, 7 - 2014.

Źródło: dane z siódmej rundy ESS, 2014 r.

\section{ZAUFANIE DO INSTYTUCJI PUBLICZNYCH I POLITYCZNYCH W ŚWIETLE WYNIKÓW JEDNO- I DWUCZYNNIKOWEJ ANALIZY WARIANCJI}

W badaniach społecznych nierzadko mamy do czynienia $\mathrm{z}$ analizą wpływu kilku zmiennych wyjaśniających (niezależnych) na jedną zmienną wyjaśnianą (zależną). Do poszukiwania zależności między zmiennymi stosuje się różne odmiany analizy wariancji, w tym także procedury analizy statystycznej, która uwzględniałaby wpływ wszystkich zmiennych wyjaśniających jednocześnie (Brzeziński, 1996; Bedyńska, Brzezicka, 2007; Rószkiewicz, 2011; Bedyńska, Cypryańska, 2013). Na zakończenie analiz postanowiono zbadać różnice w poziomie zaufania do instytucji życia publicznego i politycznego z zastosowaniem jedno- i dwuczynnikowej analizy wariancji.

Różnice w poziomie zaufania do instytucji publicznych i politycznych pomiędzy kobietami i mężczyznami są niewielkie - 0,002 pkt, a zatem raczej należałoby tu mówić o podobieństwie. 
Wykres 10.

Średnie zaufanie do instytucji politycznych i publicznych (czynnik) wg płci

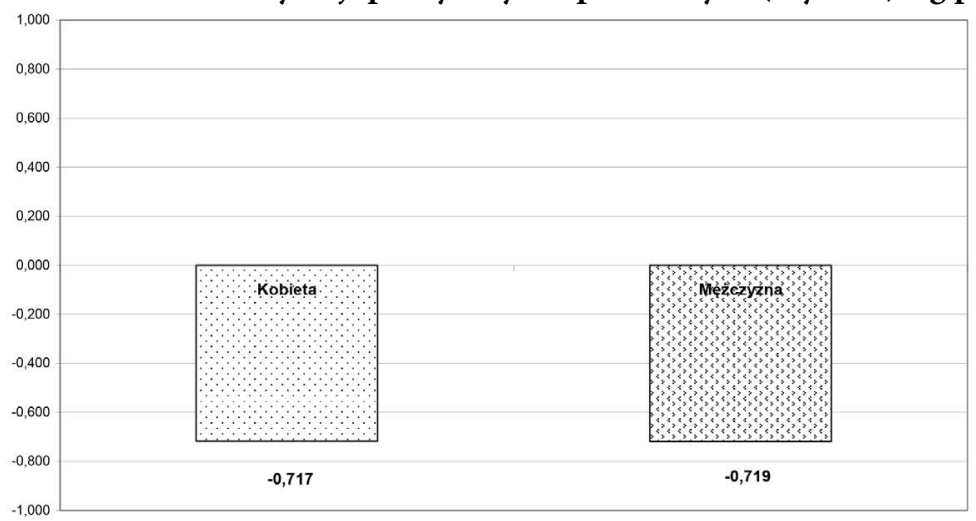

Źródło: dane z siódmej rundy ESS, $2014 \mathrm{r}$.

Jednoczynnikowa analiza wariancji pokazała, że wartości zgeneralizowanego wskaźnika zaufania w grupie kobiet i mężczyzn nie różnią się istotnie pod względem statystycznym ( $\mathrm{F}=0,002, \mathrm{df}(1), p=0,968)$.

Różnice w poziomie zaufania są wyraźniejsze, gdy dokonujemy porównania wg grup wiekowych. Porównanie średniej zaufania wewnątrz tej grupy pokazuje, że przeciętnie najwięcej zaufania do analizowanych instytucji mają osoby w wieku od 16 do 30 lat, a najmniej osoby po 66. roku życia.

Wykres 11.

Średnie zaufanie do instytucji politycznych i publicznych (czynnik) wg wieku

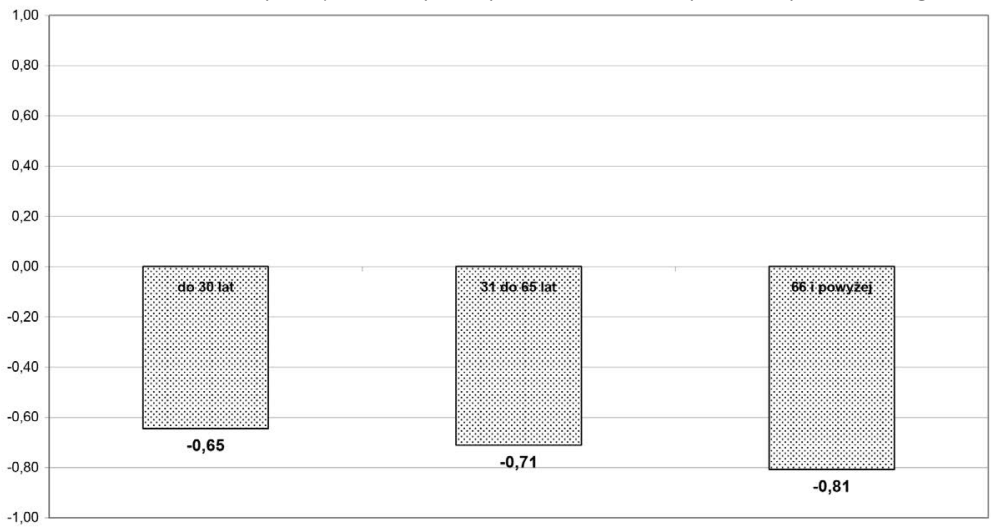

Źródło: dane z siódmej rundy ESS, 2014 r. 
Jednoczynnikowa analiza wariancji pokazała, że wartości zgeneralizowanego wskaźnika zaufania w trzech grupach wiekowych (od 16 do 30 lat, od 31 do 65 lat oraz powyżej 66 lat) różnią się między sobą istotnie pod względem statystycznym $(\mathrm{F}=3,386, \mathrm{df}(2), p<0,05)$.

Różnice w poziomie zaufania są mało widoczne, gdy porównania dokonujemy z uwagi na wykształcenie badanych. Najwyższe zaufanie odnotowano w grupie osób z wykształceniem podstawowym i wyższym. Najniższy poziom zaufania przejawiały osoby $z$ wykształceniem średnim i pomaturalnym.

Wykres 12.

Średnie zaufanie do instytucji politycznych i publicznych (czynnik) wg wykształcenia

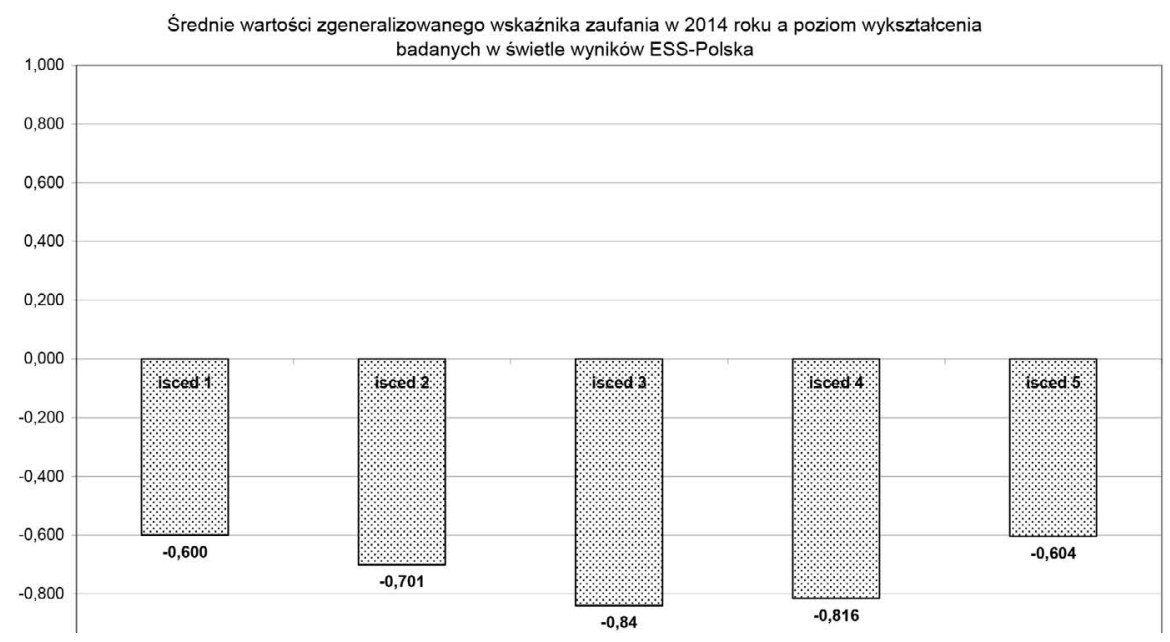

Źródło: dane siódmej rundy ESS, 2014 r.

Jednoczynnikowa analiza wariancji pokazała, że wartości zgeneralizowanego wskaźnika zaufania w grupach wykształcenia różnią się istotnie pod względem statystycznym ( $\mathrm{F}=4,653 \mathrm{df}(4), p<0,01)$.

Różnice w poziomie zaufania wg miejsca zamieszkania okazały się niewielkie. Najwyższe zaufanie do instytucji publicznych i politycznych wykazują osoby mieszkające na wsi. Najniższe - mieszkańcy dużych miast. Różnica pomiędzy tymi grupami wynosi 0,04 pkt. 
Wykres 13.

Średnie zaufanie do instytucji politycznych i publicznych (czynnik) wg miejsca zamieszkania

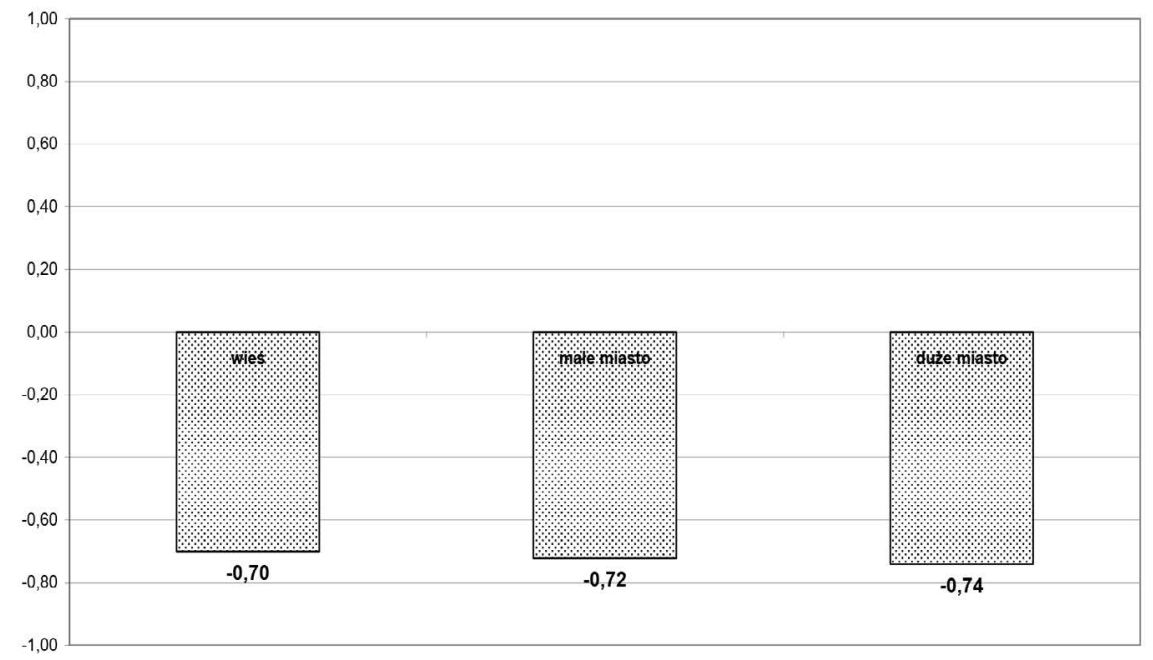

Źródło: dane siódmej rundy ESS, 2014 r.

Jednoczynnikowa analiza wariancji pokazała, że wartości zgeneralizowanego wskaźnika zaufania w trzech grupach miejsca zamieszkania (wieś, małe miasto i duże miasto) nie różnią się istotnie pod względem statystycznym $(\mathrm{F}=0,323, \operatorname{df}(2), p>0,05)$.

Zastosowanie dwuczynnikowej analizy wariancji do porównania wieku badanych i ich miejsca zamieszkania pozwoliło stwierdzić, że największe zaufanie do instytucji życia publicznego i politycznego wykazywali młodzi ludzie (do 30. roku życia) mieszkający w dużym mieście. Natomiast największą nieufnością cechowali się najstarsi respondenci, niezależnie od miejsca zamieszkania (efekt główny zmiennej wiek: $\mathrm{F}_{(2 ; 1610)}=3,069 ; p=0,043$; efekt interakcji zmiennych wiek i miejsce zamieszkania: $\left.\mathrm{F}_{(2 ; 1601)}=0,226 ; p=0,797\right)$.

W przypadku pary zmiennych wykształcenie i wiek największe zaufanie do instytucji publicznych i politycznych okazały osoby w wieku do 30 oraz od 31 do 65 lat posiadające wykształcenie niższe niż podstawowe. Natomiast najmniejszą ufność wykazywali respondenci najstarsi z najniższym wykształceniem (niższym niż podstawowe). Wynik testu efektów między- 
obiektowych okazał się nieistotny statystycznie w przypadku obu analizowanych zmiennych niezależnych (efekt główny zmiennej wykształcenie: $\mathrm{F}_{(4 ; 1639)}=2,289 ; p>0,05$; efekt główny zmiennej wiek: $\mathrm{F}_{(2 ; 1639)}=1,897$; $p>0,1$ ). Efekt interakcji zmiennych niezależnych (wiek i wykształcenie) okazał się nieistotny statystycznie (efekt interakcji zmiennych wykształcenie i wiek: $\left.\mathrm{F}_{(8 ; 1639)}=1,081 ; p>0,35\right)$.

W przypadku pary zmiennych wykształcenie i miejsce zamieszkania największym zaufaniem wykazały się osoby mieszkające w wielkim mieście i posiadające wykształcenie średnie lub pomaturalne. Natomiast największą ufnością cechowali się respondenci o najniższym wykształceniu (posiadający wykształcenie niższe niż podstawowe) mieszkający w małym lub w dużym mieście, a także osoby w wieku 31-65 lat z wyższym wykształceniem. Wynik testu efektów międzyobiektowych okazał się istotny statystycznie tylko w przypadku zmiennej wykształcenie (efekt główny zmiennej wykształcenie: $\left.\mathrm{F}_{(4 ; 1634)}=4,579 ; p<0,001\right)$. Efekt interakcji zmiennych niezależnych (miejsce zamieszkania i wykształcenie) okazał się również istotny statystycznie (efekt interakcji zmiennych wykształcenie i miejsce zamieszkania: $\left.\mathrm{F}_{(2 ; 1634)}=2,239 ; p<0,05\right)$.

\section{Podsumowanie}

Przedstawiony artykuł miał na celu pokazanie, jak analizując dane zastane pochodzące $z$ badania, którego nie byliśmy ani autorami, ani członkami zespołu analitycznego, można przy użyciu analizy czynnikowej, analizy rzetelności i analizy wariancji znaleźć odpowiedź na pytanie „komu w sferze publicznej Polacy ufają?".

Analiza czynnikowa pozwoliła na uproszczenie struktury danych badawczych. Sprowadziła istnienie pięciu zmiennych do jednego zgeneralizowanego wskaźnika zaufania. Analiza rzetelności alfa Cronbacha upewniła nas, że otrzymany zgeneralizowany wskaźnik jest zmienną o rzetelnej strukturze. Analiza wariancji pozwoliła uchwycić różnice w obrębie zmiennych niezależnych, takich jak płeć, miejsce zamieszkania, wiek i wykształcenie. I w końcu, co najważniejsze, dokonana analiza doprowadziła nas do nowych pytań już o charakterze jakościowym, których wiele zaczyna się od „dlaczego” i „co”. 
Konkludując, można powiedzieć, że Polacy są skrajnie nieufni. W sferze publicznej Polacy nie ufają ani instytucjom państwa, ani politykom, ani partiom politycznym. Zaś przeprowadzone analizy porównawcze dowodzą, że ich zaufanie jest mniejsze niż zaufanie mieszkańców państw Europy Zachodniej, Centralnej i Południowej, ale także krajów postkomunistycznych (w tym także Grupy Wyszehradzkiej). Bardzo słabym pocieszeniem jest fakt, że pod względem zaufania negatywnego Polaków wyprzedzali jedynie Słoweńcy. Analizy pokazują także, że zaufanie staje się coraz mniejsze. Ale malejące zaufanie to tendencja zauważalna w całej Europy i jednocześnie jej problem.

\section{Literatura}

Brzeziński, J. (1996). Metodologia badań psychologicznych, Warszawa: Wydawnictwo Naukowe PWN. ISBN 8301121173.

Bedyńsk, S., Brzezicka, A. (red.). (2007). Statystyczny drogowskaz. Praktyczny poradnik analizy danych $w$ naukach społecznych na przykładach $z$ psychologii, Warszawa: Wydawnictwo Szkoły Wyższej Psychologii Społecznej „Academica”. ISBN 9788389281401.

Bedyńska, S., Cypryańska, M. (red.). (2013). Statystyczny drogowskaz 2. Praktyczne wprowadzenie do analizy wariancji, Warszawa: Wydawnictwo Akademickie Sedno: Szkoła Wyższa Psychologii Społecznej. ISBN 9788363354183.

Coleman, J.S. (1988), Social capital in the creation of human capital, „American Journal of Sociology", t. 94. ISSN: 0002-9602.

Cronbach, L.J. (1946). A case study of Split-half reliability coefficient, „Journal of Educational Psychology" nr 37. ISSN 0022-0663.

Ferszt-Piłat, K. (2012). Zaufanie jako fundament bezpieczeństwa we współczesnym społeczeństwie, „Journal of Modern Science” 3/15. ISSN 1734-2031.

Frankfort-Nachmias, C., Nachmias, D. (2001). Metody badawcze w naukach społecznych, tłum. E. Hornowska, Poznań: Wydawnictwo Zysk i Spółka. ISBN 837150702X.

Fukuyama, F. (1997). Zaufanie: kapitał społeczny a droga do dobrobytu, tłum. A. i L. Śliwa, Warszawa-Wrocław: Wydawnictwo Naukowe PWN. ISBN 8301124881.

Glenn, N.D. (1978). The General Social Surveys: Editorial Introduction to a Symposium, „Contemporary Sociology” nr 7, ISSN 0094-3061.

Górniak, J. (2000). My i nasze pieniądze, Kraków: Aureus. ISBN 838788703X. 
Hyman, H.H. (1987). Secondary Analysis of Sample Surveys, Middletown: Wesleyan University Press.

Kaiser, H.F. (1960). The application of electronic computer to factor analysis, „Educational and Psychological Measurement" nr 20, ISSN 0013-1644.

Malarska, A. (2005). Statystyczna analiza danych wspomagana programem SPSS, Kraków: Predictive Solutions (dawniej SPSS Polska). ISBN 8391287122.

Nowakowski, K. (2008). Wymiary zaufania i problem zaufania negatywnego w Polsce, „Ruch Prawniczy, Ekonomiczny i Socjologiczny” t. 70, nr 1. ISSN 0035-9629.

Putnam, R.D. (1995). Demokracja $w$ działaniu: tradycje obywatelskie we współczesnych Włoszech, tłum. J. Szacki, Kraków: Znak. ISBN 978-83-240-0850-6.

Rószkiewicz, M. (2011). Analiza klienta, Kraków: Predictive Solutions (dawniej SPSS Polska). ISBN 9788391287149.

Sagan, A. (2003). Analiza rzetelności skal satysfakcji i lojalności, Kraków: Statsoft Polska.

Sztemberg-Lewandowska, M. (2008). Analiza czynnikowa $w$ badaniach marketingowych, Wrocław: Wydawnictwo Uniwersytetu Ekonomicznego. ISBN 9788370119195.

Sztompka, P. (2007). Zaufanie. Fundament społeczeństwa, Kraków: Społeczny Instytut Wydawniczy Znak. ISBN 9788324008506.

Thurstone, L.L. (1931). The measurement of social attitudes, „Journal of Abnormal and Social Psychology" nr 27, ISSN 0096-851X.

Zakrzewska, J. (1992). Państwo prawa a nowa konstytucja. W: G. Skąpska (red.), Prawo w zmieniającym się społeczeństwie, Toruń: Wydawnictwo Adam Marszałek. ISBN 8385263330.

\section{Źródła internetowe}

CBOS, Zaufanie społeczne (2016), www.cbos.pl/spiskompol/2016/K_018_16.pdf (dostęp: 12.02.2018).

Konstytucja Hiszpanii z dnia 27 grudnia 1978 r. wraz z ostatnią zmianą z 27 sierpnia 1992 r., http://libr.sejm.gov.pl/tek01/txt/konst/hiszpania.html (dostęp: 12.02.2018).

Ustawa Zasadnicza Republiki Federalnej Niemiec z 23 maja 1949 r., http://www.de-iure-pl.org/gesetze/recht/verfassung/text/1,1,741,DE,PL,html (dostęp: 12.02.2018). 
